\title{
The Effect of Climate Change on Methylmercury in Boreal Peatlands
}

CAROLINE E. Pierce ${ }^{1 *}$, STEPHEN D. SEBESTYEN ${ }^{2}$, RANDALL K. KOLKA ${ }^{2}$, NATALIE GRIFFITHS ${ }^{3}$, EDWARD A. NATER ${ }^{1}$, AND BRANDY M. TONER ${ }^{1}$

${ }^{1}$ University of Minnestota, Saint Paul, MN, *correspondence: pierc521@umn.edu

${ }^{2}$ United States Department of Agriculture, Forest Service, Grand Rapids, MN

${ }^{3}$ Oak Ridge National Laboratory, Oak Ridge, TN

Peatlands hold large quantities of atmospherically deposited mercury and can be significant sources of methylmercury (MeHg). $\mathrm{MeHg}$ is a neurotoxin produced within peatlands and exported to aquatic systems where it bioaccumulates in the food web resulting in human health effects. Because peatlands are saturated wetland systems they provide ideal conditions for methylation, so much so that the percentage of wetlands in a watershed is positively correlated with $\mathrm{MeHg}$ concentrations in fish.

This study investigated how increased temperature and elevated $\mathrm{CO}_{2}$ may impact net $\mathrm{MeHg}$ in peat porewaters and export to surface waters. Global models predict a $2-4.5^{\circ} \mathrm{C}$ increase in temperature with more drastic increases at higher latitudes, where most peatlands are located. Peatlands are expected to become drier due to reduced precipitation. The combination of these factors may turn peatlands from mercury sinks into mercury sources.

Samples were collected from 10 enclosures at the Spruce and Peatland Responses Under Changing Environments (SPRUCE) site located in Minnesota, USA. Each enclosure has above and below-ground heating, resulting in temperature treatments ranging from $+0^{\circ} \mathrm{C}$ to $+9^{\circ} \mathrm{C}$ relative to ambient. Each temperature treatment has a pair of enclosures, ambient $\mathrm{CO}_{2}$ and elevated $\mathrm{CO}_{2}$.

Porewater: Within the surface depths $(0-30 \mathrm{~cm})$, where most $\mathrm{MeHg}$ transformation occurs, there was a significant difference between $+0^{\circ} \mathrm{C}$ and $+9^{\circ} \mathrm{C}$ for both total mercury ( $\mathrm{THg}$ ) and $\mathrm{MeHg}$. Multiple linear regression identified the following factors as important for $\log 10$ transformed $\mathrm{MeHg}$ over the whole depth profile $(0-150 \mathrm{~cm})$ : Depth(-), $\mathrm{pH}(+)$, $\mathrm{THg}(+)$, iron(-), temperature $(+)$, season, and $\mathrm{CO}_{2}(+)$.

Outflow: There was a significant difference between $+0^{\circ} \mathrm{C}$ and $+9^{\circ} \mathrm{C}$ for both $\mathrm{THg}$ and $\mathrm{MeHg}$ flux. Multiple linear regeression identified the following factors as important for $\log 10$ transformed $\mathrm{MeHg}$ flux: Temperature(+), $\mathrm{THg}(+)$, iron(-), TOC(-), and season.

Our findings suggest that increased temperature will result in increased $\mathrm{MeHg}$ in porewaters and outflow and elevated $\mathrm{CO}_{2}$ will result in increased $\mathrm{MeHg}$ in porewaters. 